\section{Pulmonary Developmental Biology}

Rodolfo de Paula Vieira*

Department of Pneumology, University Hospital Freiburg, Germany

The pulmonary development is extremely complex and highly ordered, a process involving several cell types, which are involved in different phases of development, beginning in the embryonic phase until the differentiation and specialization of cells forming specialized organs [1]

The development of respiratory system (larynx, trachea, bronchi and lungs) begins in the fourth week of embryonic development, and remains incomplete until the last weeks of fetal development, becoming mature just before the birth [2,3]. Both upper (nose, nasal cavity and pharynx) and lower (larynx, trachea, bronchi and lungs) respiratory tract have its origin and development from embryonic endoderm, specifically from the digestive tube $[2,3]$.

However, several signaling via, genes and different molecules are involved in this very complex process, as fibroblast growth factor 10 [4], Trmt112 gene [5], leukemia inhibitory factor [6], homeodomain transcription factor Nkx2-1 [7], NF-kB and VEGF [8], for instance. In fact, the knowledge about the precise mechanisms of biology of pulmonary development is still poorly understood and requires a lot of effort and investments [9].

Therefore, the present special issue of Journal of Allergy and Therapy aims to present concentrate and also summarize the recent findings regarding different aspects of pulmonary development biology.

\section{References}

1. Mauad T, Rivero DH, de Oliveira RC, Lichtenfels AJ, Guimarães ET, et al.
(2008) Chronic exposure to ambient levels of urban particles affects mouse lung development. Am J Respir Crit Care Med 178: 721-728.

2. Moore KL, Persaud TV (2008) The developing human. Clinically oriented embryology (8thedn), Saunders.

3. Gilbert SF (2010) Developmental biology (9thedn), Sinauers Associate, Inc.

4. El Agha E, Al Alam D, Carraro G, MacKenzie B, Goth K, et al. (2012) Characterization of a novel fibroblast growth factor 10 (Fgf10) knock-in mouse line to target mesenchymal progenitors during embryonic development. PLoS One 7: e38452.

5. Gu T, He H, Zhang Y, Han Z, Hou G, et al. (2012) Trmt112 gene expression in mouse embryonic development. Acta Histochem Cytochem 45: 113-119.

6. Nogueira-Silva C, Piairo P, Carvalho-Dias E, Peixoto FO, Moura RS, et al. (2012) Leukemia inhibitory factor in rat fetal lung development: expression and functional studies. PLoS One 7: e30517.

7. Tagne JB, Gupta S, Gower AC, Shen SS, Varma S, et al. (2012) Genome wide analyses of Nkx2-1 binding to transcriptional target genes uncover nove regulatory patterns conserved in lung development and tumors. PLoS One 7 e29907.

8. Londhe VA, Maisonet TM, Lopez B, Jeng JM, Xiao J, et al. (2011) Conditiona deletion of epithelial IKK $\beta$ impairs alveolar formation through apoptosis and decreased VEGF expression during early mouse lung morphogenesis. Respir Res 12: 134.

9. McDougall AR, Hooper SB, Zahra VA, Sozo F, Lo CY, et al. (2011) The oncogene Trop2 regulates fetal lung cell proliferation. Am J Physiol Lung Cell Mol Physiol 301: L478-L489.
*Corresponding author: Rodolfo P. Vieira, Department of Pneumology, University Hospital Freiburg, 79106 Freiburg, Germany, Tel: 490761 881-1429, E-mail: rodrelena@yahoo.com.br

Received November 15, 2012; Accepted November 20, 2012; Published November 25, 2012

Citation: de Paula Vieira R (2011) Pulmonary Developmental Biology. J Aller Ther S7:e001. doi:10.4172/2155-6121.S7-e001

Copyright: (c) 2012 de Paula Vieira R, et al. This is an open-access article distributed under the terms of the Creative Commons Attribution License, which permits unrestricted use, distribution, and reproduction in any medium, provided the original author and source are credited. 